American Journal of Environmental Sciences 7 (4): 306-315, 2011

ISSN 1553-345X

(C) 2011 Science Publications

\title{
Land use Type Pattern and Woody Species Composition Near Human Disturbed Landscapes on Mount Makiling, Luzon Island
}

\author{
${ }^{1}$ Inocencio E. Buot and ${ }^{2}$ Katsuhiro Osumi \\ ${ }^{1}$ Institute of Biological Sciences, \\ College of Arts and Sciences, University of the Philippines Los Baños, \\ Faculty of Management and Development Studies, \\ University of the Philippines Open University, \\ Los Baños, Laguna, 4031, Philippines \\ ${ }^{2}$ Kansai Research Center, Forestry and Forest Products Research Institute, \\ Nagai-Kyutarou 68, Momoyama, Fushimi, Kyoto 612-0855, Japan
}

\begin{abstract}
Problem statement: A field study near human disturbed landscape on Mount Makiling, Luzon Island, Philippines was done on the eastern slopes of the legendary mountain to determine the land use patterns and woody species composition. Approach: Forty permanent plots of $10 \times 10 \mathrm{~m}$ in 3 belt transects spaced at $200 \mathrm{~m}$ apart were established from the undisturbed forests to the agricultural farms. Classification and ordination analysis was done. Results: Cluster analysis showed 5 land use types: the agricultural farm, forests near residences, forest edge, buffer zone and the undisturbed forests. Canonical Correspondence Analysis (CCA) indicated moderate to strong linear correlations between environmental variables and the species data (intra set correlations for altitude $=0.420$, slope $=-0.879$ and distance from farms $=-0.913$ ). The mean Basal Area (BA) was highest in the undisturbed forest and lowest in the buffer zone though the Analysis of Variance (ANOVA) showed no significant difference ( $p>0.05$ ). However, ANOVA indicated significant differences among mean stem density values $(\mathrm{p}<0.01)$ and multiple comparison using the least significant difference test (LSD), noted that the undisturbed forest had significantly lower stem density compared with the rest of the land use types $(\mathrm{p}<0.05)$. Conclusion/Recommendation: Current dominant species like Celtis luzonica and Diplodiscus paniculatus had replaced the original dipterocarps and were found occupying various elevational ranges not occupied before, indicating that past disturbances created habitats and niches favorable for colonization. It would be worthwhile to study the species biology of these present dominants as they play a significant role in stabilizing and sustaining the ecosystem. Results can give insights on the dynamics of forest landscape and the development of appropriate forest management strategy.
\end{abstract}

Key words: Anthropogenic disturbance, forest management, landscape dynamics, secondary forest, tropical mountain, Basal Area (BA), Analysis of Variance (ANOVA), Philippines Los Baños (UPLB), Plant Biology Division Herbarium (PBDH), Agricultural Farms

\section{INTRODUCTION}

When primary forests are subjected to disturbances, the otherwise lush vegetation and seemingly homogeneous landscape would drastically change. This is especially the case if anthropogenic disturbance regimes are rather severe (Heryati et al., 2011a; Muniandy et al., 2009; Gandaseca et al., 2009). The result would be various land use type patterns
(Alfred et al., 2010; Yacouba et al., 2009). Modern vegetation patterns have been shaped and continue to respond to varying degrees of human impacts (Heryati et al., 2011a; Elhadi et al., 2009).

This is the case of Mount Makiling which has always been thought of as an undisturbed primary forest partly because of legendary tales in literary works and its rich scientific history being one of the destinations of European botanical expeditions in the past (Pancho

Corresponding Author: Inocencio E. Buot, Institute of Biological Sciences, College of Arts and Sciences,

Faculty of Management and Development Studies, University of the Philippines Open University,

Los Baños, Laguna, 4031, Philippines Tel: 6349-5362893 Fax: 6349-5366010 
and Gruezo, 2006; Pancho, 1983), besides its being a forest reserve managed by the University of the Philippines Los Baños (UPLB), located at its base. However, the once serene tropical forest vegetation had been dissected into diverse patches through the years, but has never been addressed yet in scientific literatures. Hence, better understanding in the development of modern vegetation landscape on Mount Makiling with its consequent appropriate management is greatly hindered.

Fortunately, Brown (1919) had successfully documented the vegetation when Mount Makiling was still dominated by the dipterocarps which could be made as reference point for succeeding comparative studies. Payawal (1983), using cluster and ordination analyses, compared the altitudinal ranges of vegetation on Mount Makiling with the findings of Brown (1919). They found out a total of 37 major taxa showing elevational displacements of various degrees of amplitude. This indicated that anthropogenic disturbance, especially the selective logging between 1942-1944, had resulted in the creation of habitats and niches which these taxa were later able to occupy. In a later study of community structure within the presently undisturbed and protected but once loggedover forest of Mt Makiling, Luna et al., (1999), found various guilds with complex structure differing in topographic preferences, functional status and stages of succession.

The aforementioned studies are providing significant background information regarding the forest as a land use type but did not address the other land use type patterns associated with ongoing human impact developing on Mount Makiling. This needs to be understood well to shed light on the dynamics of change and to better address the issue on appropriate forest landscape management favorable for both man and nature.

In this study, the focus of the discussion is on (1) the diversity of land use type patterns on Mount Makiling using cluster analysis and (2) the environmental variables correlated with development of these patterns using canonical correspondence analysis.

\section{MATERIALS AND METHODS}

Study area: The study area was Mount Makiling, Luzon Island, Philippines (121011'E, 14008'N, 1114m altitude) (Fig. 1). It is a national park and a forest reserve situated in Los Baños, Laguna, some 65 kilometers south of Manila. Specifically, the area under investigation was mainly on the eastern slopes covering an altitudinal range of $400-510 \mathrm{~m}$ above sea level (a.s.1.).

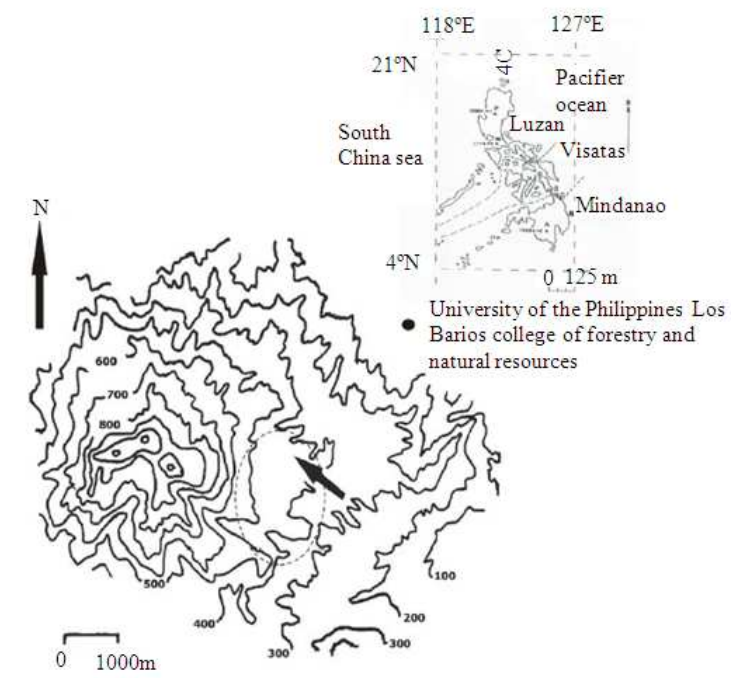

Fig. 1: The study area (enclosed by an oval as pointed by an arrow) on the eastern slopes of Mount Makiling, Los Baños, Laguna, Philippines. The Philippine map (inset) shows the location of Mount Makiling (M)

The study site was selected because of the presence of agricultural farms, residential areas and undisturbed forests in the vicinities. The biodiversity of Mount Makiling, especially the eastern portion, is generally well managed and protected by the Makiling Center for Mountain Ecosystems (MCME) of the College of Forestry and Natural Resources (CFNR), UPLB. Entry of migrants and expansion of clearings are greatly regulated.

The climate is tropical monsoon in nature with two distinct seasons as clearly presented in the climate diagram (Fig. 2). It is wet from May to December and dry, from January to April. The mean annual precipitation recorded in ten years at the UPLB Meteorological Station, College, Laguna, was 2,045mm while the mean annual temperature from the same station and in that same ten-year-period was $27.4^{\circ} \mathrm{C}$ (Fig. 2).

Establishment of plots: Three belt transects of $200 \mathrm{~m}$ interval from each other, spanning north to south direction from the most undisturbed forests to the most vulnerable agricultural farms, were established in the main study site (Fig. 1). The length of each belt was dependent on the distance from the undisturbed forest to the farms. A total of forty permanent plots were set up, thirty-five of which were $10 \times 10 \mathrm{~m}$ in size, while five were $20 \times 20 \mathrm{~m}$ in size. 


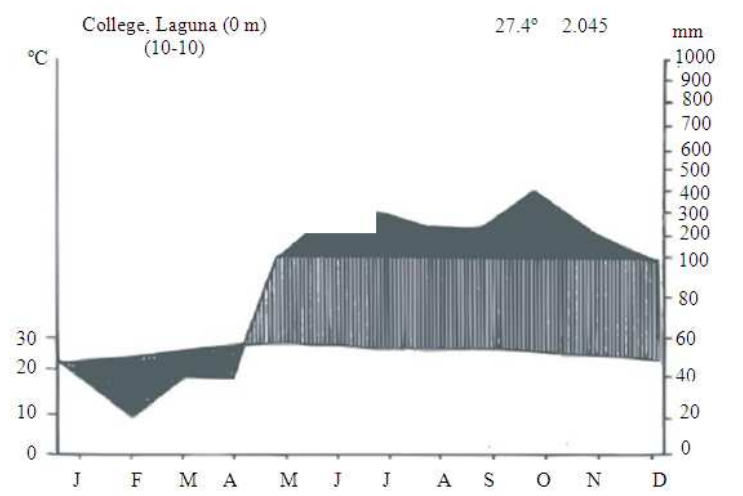

Fig. 2: The climate diagram (average of 10 years for both temperature and rainfall data) of College, Los Baños, Laguna, Philippines located at the base of Mount Makiling

Field data collection: All woody species encountered in each plot, including palms having a diameter at breast height $(\mathrm{DBH})$ of $5 \mathrm{~cm}$ or more were tagged and mapped out. The common and scientific names were identified and the DBH was recorded. Stem density was calculated while the basal area was computed from DBH data. Likewise, the slope, altitude and distance from the agricultural farms were indicated. Herbarium specimens were also prepared and deposited at the Plant Biology Division Herbarium (PBDH), Institute of Biological Sciences, College of Arts and Sciences, UPLB. Nomenclature follows that of Pancho and Gruezo (2006).

Dominance analysis: Dominance was based on the Relative Basal Area (RBA) of each species. The number of dominant species was determined quantitatively using the equation of Ohsawa (1984) as follows:

$$
d=\frac{1}{N}\left\{\sum_{i \in T}\left(x_{i}-\bar{x}\right)^{2}+\sum_{j \in U} x_{j}^{2}\right\}
$$

where, $d=$ the deviation, $x_{i}=$ the actual percent share [in this case, the RBA] of the top species (T), i.e., the top dominant in the one-dominant model, or the two top dominants in the two-dominant model and so on, $\overline{\mathrm{x}}=$ the ideal percent share based on the aforementioned model, $x_{j}=$ the percent share of the remaining species (U) and $\mathrm{N}=$ the total number of species.

Cluster analysis: The total stem density values of each species in a plot were subjected to cluster analysis using the Euclidean distance. A dendrogram was then constructed using the average linkage clustering within group (Sneath and Sokal, 1973). Each distinct cluster was indicated with the dominant species and the prevailing land use type.

Ordination analysis: In order to identify the environmental factors correlated with the species stem density data in each land use type, Canonical Correspondence Analysis (CCA) of (Gajoti et al., 2010; Ter Braak, 1986) was used. Three environmental variables, altitude, slope and distance from the agricultural farm were chosen and measured in the field.

\section{RESULTS}

Land use types on mount makiling: The total stem density values of each species in each of the 40 plots near human disturbed landscapes on Mount Makiling, were subjected to cluster analysis using the Euclidean distance. At a dissimilarity level of 7, the dendrogram (Fig. 3), constructed using the average linkage clustering within groups, shows 4 clusters or groups representing different land use types. The uppermost cluster (near residence and forest edge), however, was purposely separated due to the obvious difference in the specific type of disturbance associated with each, as actually observed in the field. The near residence site was associated with a farm house, while the forest edge was associated with an agricultural farm. Therefore at this dissimilarity level of 7 , we arbitrarily recognized 5 distinct clusters of land use types, namely, agricultural farm, area near residence, forest edge, buffer zone and undisturbed forest.

Agricultural farm refers to clearings of farmers planted to crops. Area near residence includes sites in the immediate vicinity of farm houses where farmers either reside temporarily or permanently. Forest edge is the forested area immediately next to the agricultural farm. The buffer zone is also a forested area but lies in between the forest edge and the undisturbed forest. The undisturbed forest refers to the well protected and intact forest of Mount Makiling.

Interestingly, at a dissimilarity level of around 15, the dendrogram (Fig. 3) showed only 2 distinct clusters clearly delineated by the associated disturbance regime. The cluster associated with an anthropogenic disturbance (agricultural farm, near residence and forest edge) and the more or less stable cluster, relatively free from human activity, composed of the buffer zone and the undisturbed forest are clear and evident. 
Am. J. Environ. Sci., 7 (4): 306-315, 2011

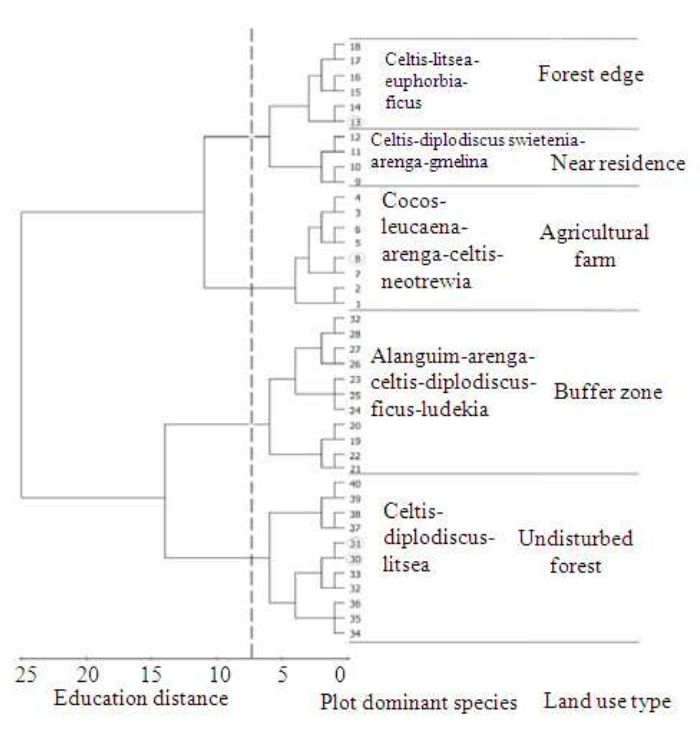

Fig. 3: The dendrogram constructed by average linkage within groups of the Euclidean distance showing 5 land use types and their respective dominant species from among 40 plots

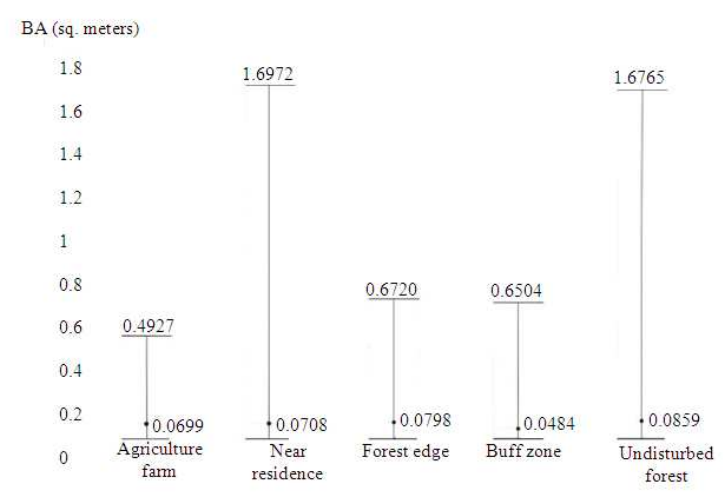

Fig. 4: The maximum and mean basal area (BA) values (sq $\mathrm{m} / 100 \mathrm{sq} \mathrm{m}$ ) of the the 5 land use types

This suggests that stem density as the species variable used in the cluster analysis was indeed reflective of the actual field conditions.

Floristic composition and dominant species in each land use type: The details of the structural characteristics of the species composition in each of the aforementioned land use types are indicated in Table 1. A total of 89 species in 72 genera and 42 families were recorded from 40 plots having an aggregate area of 0.55 hectare. The species are arranged alphabetically within genera and within families respectively with their abbreviations as used in the statistical analysis and the common names for convenience in case someone has to trace in the locality. The RBA and the Relative Density (RD) of each species in a land use type are also indicated to allow comparison of these values.

The number of species in each land use type varied as expected (Table 1). The frequently disturbed land use types, the agricultural farms, near residences and forest edges had only 17, 19 and 25, respectively. This is considerably lower compared with the buffer zone (45) and the undisturbed forest (45), obviously because man selected to a large extent what species he had wanted to grow in his farm or near his residence. Incidentally, the buffer zone and the undisturbed forest had the same total number of species, though not necessarily identical (Table 1).

Using Ohsawa (1984) model in determining the number of dominant species per land use type, the agricultural farm had 8 dominant species (Table 2 and those with asterisk * in Table 1), areas near residences had 6, the forest edge had 5, the buffer zone had 7, while the undisturbed forest had 3. A number of similar dominant species occurred in many land use types as dominants as well (Table 2). Arenga pinnata, Celtis luzonica and Diplodiscus paniculatus were prominent examples of these important species on Mount Makiling.

The mean and maximum BA values for $100 \mathrm{sq} \mathrm{m}$ were also compared across land use types (Fig. 4). The buffer zone had the lowest mean BA while the undisturbed forest had the highest mean. The maximum BA however, was highest in near residence and undisturbed forest and lowest in agricultural farm. This is indeed possible on Mount Makiling, since all activities in the park are now being closely managed and monitored by the UPLB authorities. Residents are bound by a contract not to cut existing trees even if these are near residences or agricultural farms. Hence, it is not unusual to find older stands of trees growing in patches near agricultural farms and near residences (Table 1 and 2) and some of them even exceeded the BA values of trees in the undisturbed 6 forests (Fig. 4). Nevertheless, the analysis of variance (ANOVA) did not show any significant difference among mean BA values across land use types ( $\mathrm{p}$-value $>0.05$ ).

Stem density, (Table 1) was also analyzed. ANOVA showed significant differences in mean stem density among land use types (p-value $<0.01$ ). Multiple comparisons using the least significant difference test (LSD) indicated that the mean stem density of the undisturbed forest was significantly different from the mean stem density of all the other land use types ( $\mathrm{p}$-value<0.05). 
Am. J. Environ. Sci., 7 (4): 306-315, 2011

Table 1: Species composition of the 5 land use types on Mount Makiling showing Relative Basal Area (RBA) and Relative Density (RD). Species are arranged alphabetically in genera and in families. Dominant species are indicated with asterisk (*)

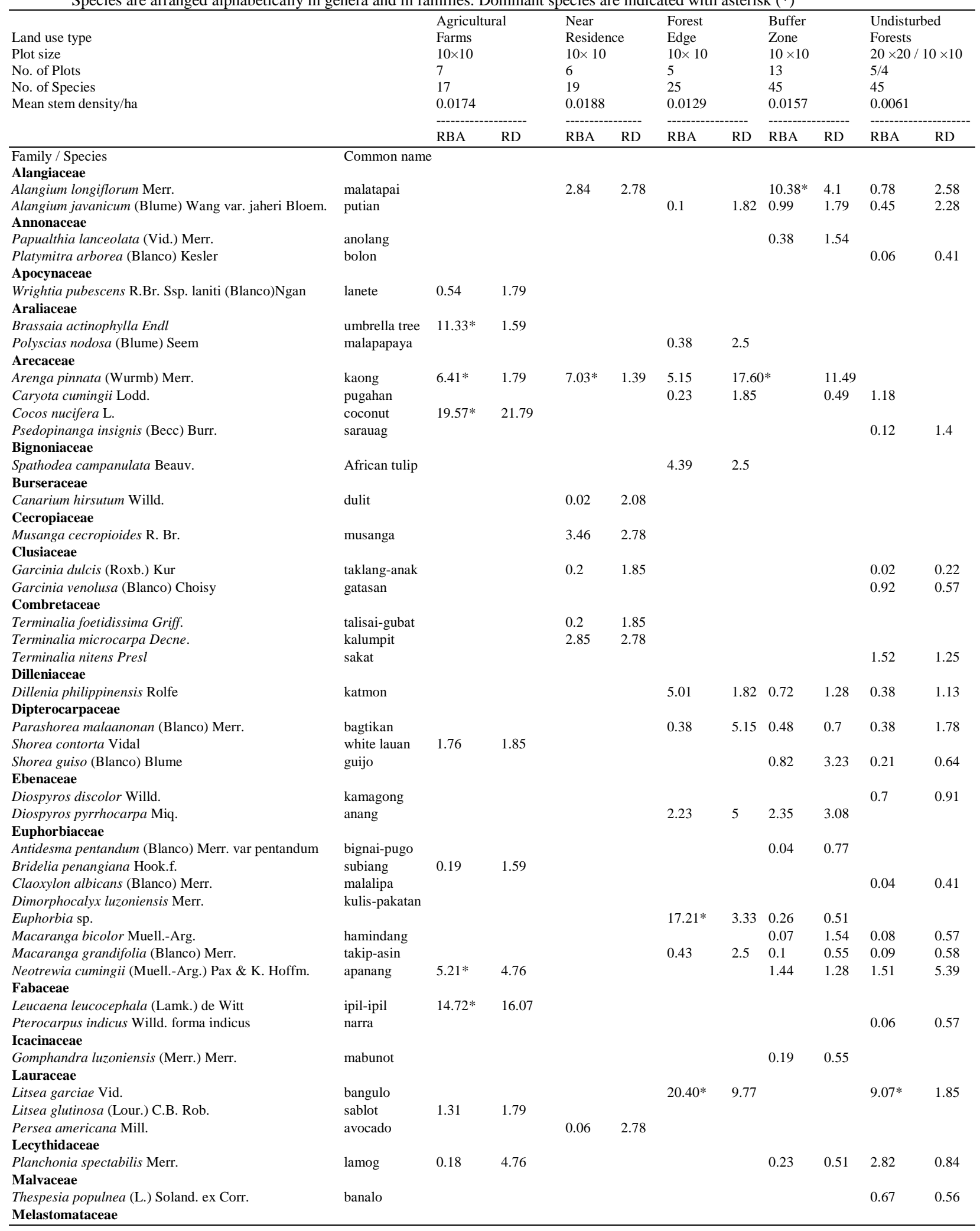


Am. J. Environ. Sci., 7 (4): 306-315, 2011

Table 1: Continuous

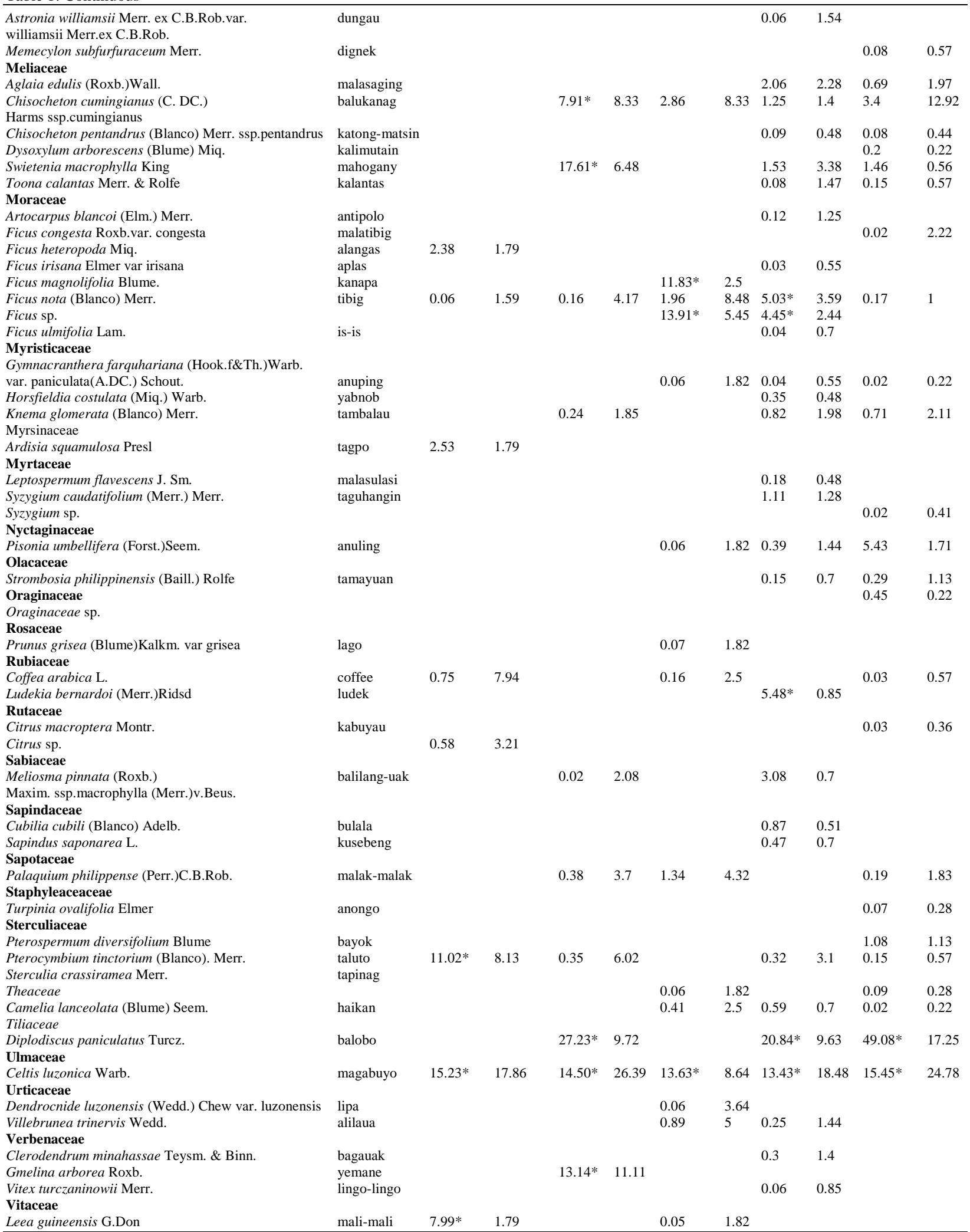


Am. J. Environ. Sci., 7 (4): 306-315, 2011

Table 2: Occurrence of dominant species in various land use types on Mount Makiling

\begin{tabular}{|c|c|c|c|c|c|}
\hline Dominant species & $\begin{array}{l}\text { Agricultural } \\
\text { Farms }\end{array}$ & $\begin{array}{l}\text { Near } \\
\text { Residence }\end{array}$ & Forest Edge & Buffer Zone & $\begin{array}{l}\text { Undisturbed } \\
\text { Forest }\end{array}$ \\
\hline Alangium longiflorum Merr. & - & - & - & + & - \\
\hline Arenga pinnata (Wurmb) Merr. & + & + & - & + & - \\
\hline Brassaia actinophylla Endl. & + & - & - & - & - \\
\hline Celtis luzonica Warb. & + & + & + & + & + \\
\hline \multicolumn{6}{|l|}{ Chisocheton cumingianus (C. DC.) Harms } \\
\hline ssp.cumingianus & - & + & - & - & - \\
\hline Cocos nucifera $L$. & + & - & - & - & - \\
\hline Diplodiscus paniculatus Turcz. & - & + & - & + & + \\
\hline Euphorbia sp. & - & - & + & - & - \\
\hline Ficus magnolifolia Blume. & - & - & + & - & - \\
\hline Ficus nota (Blanco) Merr. & - & - & - & + & - \\
\hline Ficus sp. & - & - & + & + & - \\
\hline Gmelina arborea Roxb. & - & + & - & - & - \\
\hline Leea guineensis G.Don & + & - & - & - & - \\
\hline Leucaena leucocephala (Lamk.) de Witt & + & - & - & - & - \\
\hline Litsea garciae Vid. & - & - & + & - & + \\
\hline Ludekia bernardoi (Merr.)Ridsd. & - & - & - & + & - \\
\hline Neotrewia cumingii (Muell.-Arg.) Pax \& K. Hoffm. & + & - & - & - & - \\
\hline Pterocymbium tinctorium (Blanco). Merr. & + & - & - & - & - \\
\hline Swietenia macrophylla King & - & + & - & - & - \\
\hline
\end{tabular}

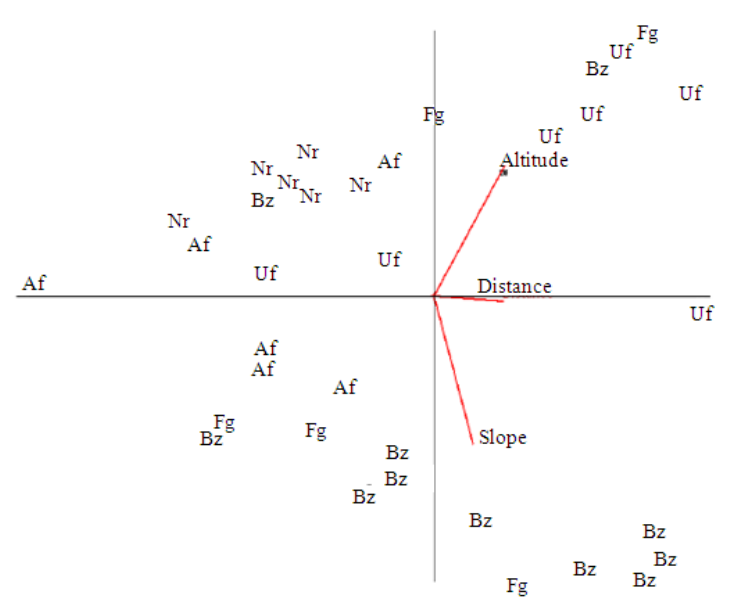

Fig. 5: Ordination diagram using the canonical correspondence analysis (CCA) of Ter Braak (1986, 1994), showing a linear relationship between the species data (stem density) and the environmental variables, altitude, slope and distance from the agricultural farm $(\mathrm{Ag}=$ agricultural farm, $\mathrm{Nr}=$ near residence, $\mathrm{Fg}=$ forest edge, $\mathrm{Bz}=$ buffer zone, $\mathrm{Uf}=$ undisturbed forest)

Environmental variables related to species variation: The CCA multiple correlations (the intra set correlations of Ter Braak, 1986) (Table 3) and the CCA graph (Fig. 5) revealed linear relationship between the species data (stem density) and the three CCA axes, represented by altitude as axis $1(\mathrm{R}=0.420)$, slope as axis $2(\mathrm{R}=-0.879$ and distance from the agricultural farm as axis $3(\mathrm{R}=-0.913)$.

Many plots of Undisturbed Forests (Uf) were influenced by altitude and were quite far from the Agricultural Farms (Af), which were generally found in lower altitudes and gentle slopes as the near residence $(\mathrm{Nr})$ plots. If ever, residences were situated in higher altitudes, they were in moderately gentle slopes (Fig. 5). In contrast, buffer zones (Bz), were almost always in steeper slopes. Forest edges (Fg), follow the trend of the agricultural farms.

\section{DISCUSSION}

Results showed diverse land use types in a belt transect spanning from the undisturbed forest to an agricultural farm. The once homogeneous tropical rain forest landscape on Mount Makiling, has now diverse land use types (Fig. 3), in the study area, particularly on the eastern side of the mountain (Fig. 1). The arbitrarily designated land use types are clearly distinct and well delineated by the species stem density data (Fig. 3).

A totally different group of species are dominating on Mount Makiling now (Table 1-2) as compared with the original vegetation reported by Brown (1919). The dominating dipterocarps in 1919 were selectively logged and heavily harvested between 1942-1944 (Payawal, 1983; Luna et al., 1999; Lasco et al., 2001). 
Am. J. Environ. Sci., 7 (4): 306-315, 2011

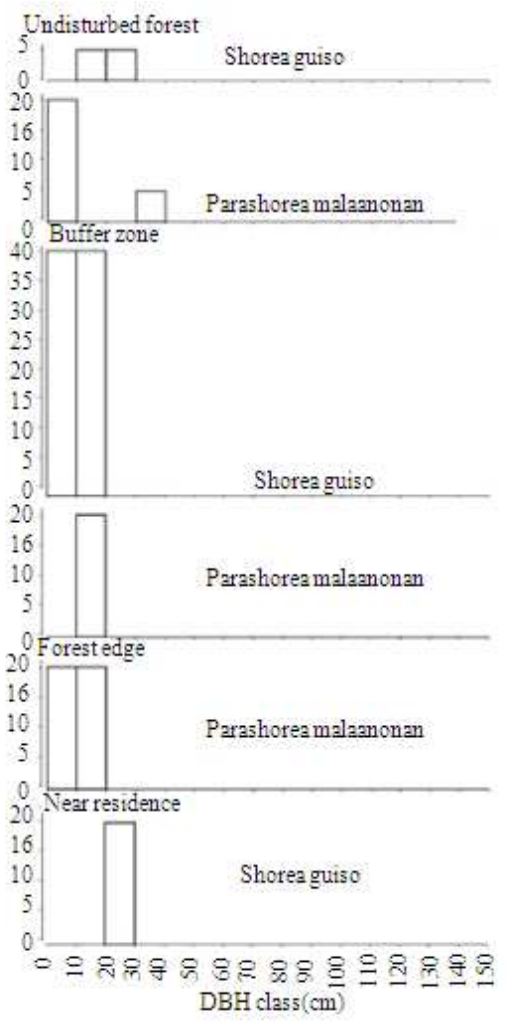

Fig. 6: The diameter at breast height (DBH) class distribution of the three species of dipterocarps, the former dominants of the forest landscape on Mount Makiling

Table 3: Canonical coefficients and intra set correlations of experimental variables with the 3 axes of CCA for the Mt. Makiling data (axis 1-altitude, axis 2-slope and axis 3distance from farms).

\begin{tabular}{|c|c|c|c|c|c|c|}
\hline \multirow[b]{2}{*}{ Variable } & \multicolumn{3}{|c|}{ Coefficients } & \multicolumn{3}{|c|}{ Correlations } \\
\hline & Axis 1 & Axis 2 & Axis 3 & Axis 1 & Axis 2 & Axis 3 \\
\hline Distance & 0.633 & -0.053 & -0.35 & 0.406 & -0.029 & -0.913 \\
\hline & & & -0 & 0.233 & -0.879 & 0.417 \\
\hline altitude & 0.706 & -0.297 & 0.222 & 0.42 & 0.782 & 0.46 \\
\hline
\end{tabular}

Eigenvalues for axes $1=0.483,2=0.388$ and $3=0.260$; Total variance (inertia) in species data: 11.7412

So far, in the study site, only three species of dipterocarps were noted, Shorea contorta, S. guiso and Parashorea malaanonan. The three species were still occupying the lower DBH classes and only in four land use types of this study (Fig. 6). Judging from the results as shown in Fig. 6, it will still have to take several years before the dipterocarps can regain dominance over the forest landscape on Mount Makiling, even under the present set up, where the mountain is a national park and a forest reserve managed by UPLB.
It has been repeatedly emphasized in literature that factors causing landscape heterogeneity are either natural or anthropogenic in nature or a combination of both (Alfred et al., 2010; Solaimani et al., 2009; Elhadi et al., 2009; Marian et al., 2009). Natural factors can be site factors such as soil, elevation, slope or disturbances as typhoons and landslides. These can induce distinct patches in a matrix and produce a heterogeneous landscape. Similarly, human clearings and croplands can result to diversity of patches depending on the magnitude of activity.

In the present study, altitude, slope and distance from the agricultural farms had been linearly correlated with the species stem density in various land use types (Fig. 5). The results confirmed that site factors are considered main important determinants of landscape heterogeneity as previously reported by (Suzuki et al., 2002). Thus, most of the undisturbed forests on Mount Makiling were located in higher altitudes and many buffer zones were in steeper slopes (Fig. 5). Higher altitudes and steeper slopes posed some difficulty for humans to establish their farms and farm houses. Consequently, human disturbances on Mount Makiling, created patches of agricultural farms and residences situated in lower altitudes and moderate slopes at a considerable distance from the undisturbed forest plots.

CCA results, however, could explain only $11.74 \%$ of the variance in the data (Table 3), implying that there should be more environmental variables that could possibly explain the variation but were not included in the analysis. These environmental variables, known and established to cause variation in species data may include precipitation (Buot and Okitsu, 1999, Ohsawa 1995), temperature (Buot and Okitsu, 1999; Richards, 1952), humidity (Richards, 1952), soil conditions (Heryati et al., 2011b, Suzuki et al., 2002), microbial composition, natural disturbances particularly, typhoon, erosion and landslides and anthropogenic disturbance history (Heryati et al., 2011a; Muniandy et al., 2009; Hong et al., 1995; Osumi et al., 2003). However, more works and experiments have to be done in testing these variables on Mount Makiling.

\section{CONCLUSION}

The role of the University of the Philippines Los Baños (UPLB) in implementing the Philippine forest policy so as to regulate the further spread of various land use types on Mount Makiling should have contributed to the present vegetation pattern as well. Knowing that the original dominants, the dipterocarps, will still have a long way to regain dominance over the forest landscape, it is urgent to do intensive studies on 
the present dominants, Celtis luzonica, Diplodiscus paniculatus and Ficus spp. These species play a very significant role in stabilizing and sustaining the ecosystem landscape. Elucidating the species biology of these dominants will shed light on the dynamics of the once logged-over forest landscape on Mount Makiling and even other southeast Asian mountain forests for that matter. Hopefully, when these data will be made available on hand, we can finally develop appropriate forest landscape management system favorable to both the forest and the human population living in the uplands.

\section{ACKNOWLEDGEMENT}

The researchers are grateful to Dr. Edwino S. Fernando, then Director of the Makiling Center for Mountain Ecosystems (MCME), College of Forestry and Natural Resources (CFNR), University of the Philippines Los Baños (UPLB), Dr. Emmanuel Abraham, the then Superintendent of the Makiling Forest Reserve, MCME and Ms. Amelita C. Luna of the Office of the Coordinator for Research and Extension, CFNR, for facilitating the fieldwork. The Japan Society for the Promotion of Science (JSPS) through the Forestry and Forest Products Research Institute (FFPRI), Japan, awarded a postdoctoral fellowship to the senior author.

\section{REFERENCES}

Alfred, R., K.P. Hue, L.S. Khee and R. Alfred, 2010. Summarizing spatial distribution density, movement patterns and food resources to study the impacts of logging and forest conversion on orangutan population. OnLine J. Biol. Sci., 10: 73-83. DOI: $10.3844 /$ ojbsci.2010.73.83

Brown, W.H., 1919. Vegetation of Philippine Mountains: The Relation Between the Environment and Physical Types At Different Altitudes. 1st Edn., Bureau of Printing, Manila, pp: 434.

Buot I.E. and S. Okitsu, 1999. Leaf size zonation pattern of woody species along an altitudinal gradient on Mt. Pulog, Philippines. Plant Ecol., 145: 197-208. DOI: 10.1023/A:1009868305586

Elhadi, E.M., N. Zomrawi and H. Guangdao, 2009. Landscape change and sandy desertification monitoring and assessment. Am. J. Environ. Sci., 5: 633-638. DOI: 10.3844/ajessp.2009.633.638

Gajoti, T.E., V. Haciyev, A. Javanshir, H. Nosrati and A.R. Haghighi et al., 2010. Vegetation analysis of sutan-chay basin in arasbaran. Am. J. Agric. Biol.
Sci., 5: 357-362. DOI:

10.3844/ajabssp.2010.357.362

Gandaseca, S., J. Sabang, O.H. Ahmed and N.M.A. Majid, 2009. Vegetation assessment of peat swamp forest using remote sensing. Am. J. Agric. Biol. Sci., 4: 167-172. DOI: 10.3844/ajabssp.2009.167.172

Heryati, Y., A. Abdu, M.N. Mahat, H. Abdul-Hamid and S. Jusop et al., 2011a. Assessing forest plantation productivity of exotic and indigenous species on degraded secondary forests. Am. J. Agric. Biol. Sci., 6: 201-208. DOI: 10.3844/ajabssp.2011.201.208

Heryati, Y., A. Abdu, M.N. Mahat, H. Abdul-Hamid and S. Jusop et al., 2011b. Comparing the fertility of soils under Khaya ivorensis plantation and regenerated degraded secondary forests. Am. J. Applied Sci., 8: 472-480. DOI: 10.3844/ajassp.2011.472.480

Hong, S.K., N. Nakagoshi and M. Kamada, 1995. Human impacts on pine-dominated vegetation in rural landscapes in Korea and western Japan. Plant Ecol., 116: 161-172. DOI: 10.1007/BF00045306

Lasco R.D., R.G. Visco and J.M. Pulhin, 2001. Secondary forests in the Philippines: Formation and transformation in the 20th century. J. Tropical Forest Sci., 13: 652-670.

Luna, A.C., K. Osumi, A.F. Gascon, R.D. Lasco and A.M. Palijon et al., 1999. The community structure of a logged-over tropical rain forest in Mt. Makiling Forest Reserve, Philippines. J. Tropical Forest Sci., 11: 446-458.

Marian, M., L.M. Cozmuta, C. Varga, A. M. Cozmuta and E. Nour, 2009. Vegetation dynamics depending on ecological particularities of bozanta mare (Maramures County-Romania) tailing pound. case study. Am. J. Environ. Sci., 5: 116-123. DOI: 10.3844/ajessp.2009.116.123

Muniandy, M., O.H. Ahmed, N.M.A. Majid and M.K. Yusop, 2009. Effects of converting secondary forest to oil palm plantation on peat soil carbon and nitrogen and other soil chemical properties. Am. J. Environ. Sci., 5: 406-412. DOI: 10.3844/ajessp.2009.406.412

Ohsawa, M., 1984. Differentiation of vegetation zones and species strategies in the subalpine region of Mt. Fuji. Plant Ecol., 57: 15-52. DOI: 10.1007/BF00031929

Ohsawa, M., 1995. Latitudinal comparison of altitudinal changes in forest structure, leaf-type, and species richness in humid monsoon Asia. Plant Ecol., 121: 3-10. DOI: 10.1007/BF00044667 
Osumi, K., S. Ikeda and T. Okamoto, 2003. Vegetation patterns and their dependency on site conditions in the pre-industrial landscape of north-eastern Japan. Ecol. Res., 18: 753-765. DOI: 10.1111/j.14401703.2003.00593.x

Pancho, J.V. and W.S. Gruezo, 2006. Vascular flora of Mount Makiling and Vicinity: Part 2. National Academy of Science and Technology, Philippines, Department of Science and Technology, Bicutan, Taguig City and Institute of Biological Sciences, University of the Philippines Los Baños, College, Laguna, Philippines. ISBN: 971853878X

Pancho, J.V., 1983. Vascular flora of Mount Makiling and Vicinity (Luzon, Philippines). 1st Edn., New Mercury Printing Press, Quezon City, Philippines.

Payawal, P.C., 1983. Vegetation and modern pollen rain of Mt. Makiling, Philippines. II. Pollen analysis of surface soil. Kalikasan, 12: 317-327. http://md1.csa.com/partners/viewrecord.php?reque ster $=$ gs\& collection $=$ ENV \& recid $=962713$

Richards, P.W., 1952. The Tropical Rain Forest: An Ecological Study. 2nd Edn., Cambridge University Press, Cambridge, pp: 450.
Solaimani, K., S. Modallaldoust and S. Lotfi, 2009. Soil erosion prediction based on land use changes (a case in neka watershed). Am. J. Agric. Biol. Sci., 4: 97-104. DOI: 10.3844/ajabssp.2009.97.104

Suzuki W., K. Osumi, T. Masaki, K. Takahashi and H. Daimaru et al., 2002. Disturbance regimes and community structures of a riparian and an adjacent terrace stand in the Kanumazawa Riparian Research Forest, northern Japan. Forest Ecol. Manage., 157: 285-301. DOI: 10.1016/S03781127(00)00667-8

Ter Braak, C.J.F., 1986. Canonical correspondence analysis: A new eigenvector technique for multivariate direct gradient analysis. Ecology, 67: 1167-1179. DOI: $10.2307 / 1938672$

Ter Braak, C.J.F., 1994. Canonical community ordination. Part I: Basic theory and linear methods. Ecoscience, $\quad 1$ : 127-140. http://citeseerx.ist.psu.edu/viewdoc/download?doi= 10.1.1.73.7097\&rep=rep1\&type $=$ pdf

Yacouba, D., H. Guangdao and A.H. Abdulahi, 2009. Simulation Planning for Sustainable Use of Land Resources: Case study in Diamou. J. Math. Stat., 5: 15-23. DOI: 10.3844/jmssp.2009.15.23 